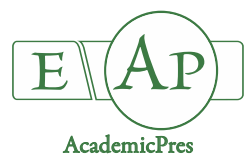

\title{
Application of ITAP-PCR Techniques to Assess the Genetic Variability of Selected Cultivars of Winter Triticale ( $\times$ Triticosecale Wittmack)
}

\author{
Izabela SZUĆKO ${ }^{1,2 *}$, Anna MĄDRACH ${ }^{1}$ \\ ${ }^{1}$ University of Szczecin, Faculty of Biology, The Institute for Research on Biodiversity, Department of Molecular Biology and Cytology, Waska 13, \\ 71-415 Szczecin, Poland; izabela.szucko@usz.edu.pl ('corresponding author); annamadrach@wp.pl \\ ${ }^{2}$ Centre for Molecular Biology and Biotechnology, Waska 13, 71-415 Szczecin, Poland
}

\begin{abstract}
The increasing use of triticale ( $\times$ Triticosecale Wittmack) indicates that its position on the seed market is constantly strengthening; therefore, the research on its genetic variability is necessary to improve breeding process of new cultivars. The aim of the study was to assess the possibility of using the ITAP-PCR technique to analyse the genetic similarity of nine cultivars of winter triticale cultivated in Poland. Primers designed on the basis of 6 DNA transposon sequences commonly found in cereal plant genomes were used for the study. The average polymorphism rate in the genotypes used in the study was determined as 95.24\%; in total, 75 bands were obtained, of which 73 were polymorphic. The PIC value ranged between 0.27 and 0.44 , and was highest for the Hamlet primer. The lowest PIC value was observed for the Mutator primer. The average DI value was 0.34 , MI - 4.08, AEI - 12.17 and IPI - 4.40. SI ranged from $36.7 \%$ to $1.7 \%$. A dendrogram was created according to the unweighted pair group method with arithmetic mean (UPGMA), which in terms of genetic similarity divided the analysed winter triticale cultivars into two main similarity groups. We confirmed that ITAP technique of transposon-based marker is efficient and fast method to detect genetic variability between different winter triticale cultivars. In addition, the presence of analyzed transposon families in hexaploid triticale has not been studied earlier.
\end{abstract}

Keywords: CACTA; molecular markers; $M u$; Revolver; triticale; transposon; transposable DNA elements

\section{Introduction}

Triticale is a species, especially important from the point of view of breeders. Triticale ( $\times$ Triticosecale Witt.) is an allopolyploid organism derived from chromosome doubling of hybrids between two genera: Triticum and Secale. Triticale is the youngest cereal crop and the first graminoid synthesized by humans ( $\mathrm{Ma}$ and Gustafson, 2008). In Poland, the production of this cereal over the years amounts to as much as 5 million tons (annually about 4370 thousand tons). Germany and Belarus are also among the leading European countries growing triticale - about 3 million tons (Achremowicz et al., 2015). These values indicate the high economic importance of triticale, and the reason is very good yielding and the combination of many desirable traits from parental species - wheat and rye. Triticosecale does not have significant soil requirements, the grain contains high protein content, and above all, it is a species resistant to diverse environmental conditions and the continuous emergence of fungal pathogens, such as powdery mildew and septoria leaf blotch (Alheit et al., 2011; Kramek and Kociuba, 2014). This cereal is currently used for animal food and biofuel production; it is also relevant for erosion control and as a cover crop (Machczyńska et al., 2015; Ramirez-Garcia et al., 2015). Due to the wide spectrum of usability of this cereal, it is extremely important to constantly improve existing forms or create new cultivars. However, it should be noted that stable plant genotypes, with a wide range of adaptive abilities regarding traits useful for breeders, play a significant role in modern plant breeding. On the other hand, breeding material, such as triticale is characterized by a large genetic similarity, which is not a favourable phenomenon for breeding new cultivars. It is important for the breeding material to be genetically diverse (Kramek and Kociuba, 2014). In modern breeding, the correct selection of triticale using heterosis phenomenon to create productive hybrids characterized by high grain quality is extremely important. It is known that crossing genetically distant forms is more beneficial for creating heterotic hybrids than those that are closely related (Orlovskaya et al., 2012). Therefore, it seems important to analyse the genetic links between constantly cultivated triticale cultivars, so that they can become a source of genes for new cultivars. Earlier literature reports indicate that morphological markers were used to estimate 
948

genetic variation in triticale (Kamboj and Mani, 1983; Furman et al., 1997). Currently, dynamically developing molecular biology tools are applied for this type of analysis. Molecular markers are essential in plant and animal breeding and biodiversity applications as well as for the map-based cloning of genes (Kuleung et al., 2006; Kalendar et al., 2011).

Transposable elements that play an important role in the evolution of monocotyledonous plants, grasses in particular, constitute about $60-85 \%$ of their genome. Knowledge of the mechanisms of functioning of these elements allows understanding the diversity of plant organisms (Lu et al., 2017). Transposons are repetitive DNA sequences that have the ability to transpose (move) from one location in the genome to another. TEs (Transposable Elements) are classified into two main groups, based on the intermediate molecule that mediates their movement: i) class I transposons (retrotransposons or RNA elements) have RNA as their intermediate molecule and ii) class II transposons (DNA elements) have DNA as their intermediate molecule (Yaakov and Kashkush, 2011). Each class is sub-divided into a number of 'superfamilies', which share common structures, sequence homologies and detailed transposition mechanisms (Muehlbauer et al., 2006). Class II elements were discovered through genetic analysis of mutant alleles and include the $A c / D s$ and Spm/dSpm elements of maize (McClintock, 1954), the $P$ element of Drosophila (Bringham et al., 1982) and the Tc1/mariner elements of Caenorhabditis elegans (Emmons et al., 1983).

The mechanism of "jumping genes" can affect gene continuity, and thus lead to phenotypic differences (Rogalska et al., 2004; Yaakov and Kashkush, 2011). It is the transposition mechanism that causes mobile elements to induce mutations, thereby affecting gene expression regulation by enhancing or silencing their effect. Transposition of TEs leads to a variety of lesions in the surrounding DNA such as duplications, inversions, translocations and deletions. The activity of transposons is influenced by stress factors, both abiotic, e.g. irradiation, temperature and biotic, i.e. viral or pathogenic infections. Transposition can also be activated by the so-called genomic shock, i.e. programmed response to stress induced by hybridization (Szućko and Rogalska, 2015; Kalinka and Achrem, 2018). Transposons, by regulating host stress response, can help generate a new, better genotype that will exhibit greater adaptation to stress (Bieniek, 2006; Seidl and Thomma, 2017).

Considering the functionality and the dominant presence of TEs in plant genomes, they may be useful in programs aimed at improving the genotypes of cultivated species (Gao et al., 2015). Transposable elements are also strong mutagens of plant genomes, and hence the most immediate consequence of their activity is the formation of mutants that are manifested by the presence of various changes in the genome.

It was shown on the basis of comparative analysis of closely related plant grass genomes that the amplification of mobile elements is responsible for the high variability of the genome, not only at the interspecific but also intraspecific level. Several studies detecting the genetic diversity in plants using transposable element-based markers have been published, and they mostly used retrotransposon-based markers, e.g. inter-retrotransposons amplified polymorphism (IRAP), retrotransposon-microsatellite amplified polymorphism (REMAP) (Kalendar, 2011; Trebichalsky et al., 2013; Szućko and Roglaska, 2015; Kalinka and Achrem, 2018), retrotransposon-based insertion polymorphism (RBIP) (Flavell et al., 1998), interprimer binding sequence (IPBS) (Kalendar et al., 2010) and sequence-specific amplification polymorphism (SSAP). This is due to the fact that the vast majority of mobile elements found in plant genomes belong to TE class I.

Mobile elements are a valuable source in the studies on polymorphism and genetic diversity in plants (Szućko, 2013), therefore this study used the pioneer ITAP-PCR marker system (inter-transposons amplified polymorphism PCR, developed by Szućko and Rogalska (2015)) to assess the degree of DNA transposon nucleotide sequence rearrangements and their genetic diversity in selected cultivars of commonly grown winter triticale. The principle of this method is the amplification of regions located between two DNA transposons belonging to the same family. Thanks to this technique, the scale of rearrangement of DNA mobile elements fragments can be assessed and the genetic variability of the analysed individuals can be estimated.

\section{Materials and Methods}

\section{Plantmaterial}

The plant material consisted of nine cultivars of winter triticale ('Bolero', 'Bogo', 'Janko', 'Kazo', 'Lamberto', 'Moreno', 'Prego', 'Presto' and 'Pronto'), obtained from the National Centre for Plant Genetic Resources, Radzików Poland and Danko Breeding Co. Ltd.

\section{DNA extraction and PCR amplification}

The probes of genomic DNA were isolated from coleoptiles ( $0.2 \mathrm{~g}$ per sample) of etiolated seedlings. DNA extraction was performed using the GeneMATRIX Plant\&Fungi DNA purfication kit (EURx, Gdańsk, Poland). Both DNA quality and concentration were assessed by agarose gel electrophoresis and spectrophotometry (NanoDrop 2000; Thermo Scientific).

Amplification was carried out using primers designed by Szućko and Rogalska (2015). Primers for ITAP were designed to amplify TIR regions of the 5 'end of different transposons. After preliminary tests, primers which showed polymorphism between triticale cultivars were chosen for further analysis, i.e. designed for TIR sequences of Caspar (HE774675.1), Jude (HE774675.1), Mutator (JF701619.1), Revolver (AB646254.1), Sherlock (HE774675.1) (Szućko and Rogalska, 2015) and Hamlet (HE774675.1) transposons.

All primers were synthesized at the Institute of Biochemistry and Biophysics (the Polish Academy of Sciences, Warszawa, Poland) and at Genomed S.A. (Warszawa, Poland).

The PCR reaction was carried out in duplicate using a $\mathrm{T}_{100}{ }^{\text {mix }}$ Thermal Cycler (Bio-Rad). A single PCR reaction mixture contained: $1 \times$ standard Taq polymerase buffer, 0.2 - 
$0.25 \mathrm{mM}$ dNTP, $2.25 \mathrm{mM} \mathrm{MgCl}$, 1-1.5 $\mu \mathrm{M}$ of each primer, 10-15 ng genomic DNA and 2-3 U Allegro DNA Polymerase (Novazym, Poland). The PCR program was as follows: $94^{\circ} \mathrm{C}$ for $3 \mathrm{~min} ; 40$ cycles with $94^{\circ} \mathrm{C}$ for $60 \mathrm{~s}, 51.5$ ${ }^{\circ} \mathrm{C}$ to $58{ }^{\circ} \mathrm{C}$ for $1 \mathrm{~min}$, and $72{ }^{\circ} \mathrm{C}$ for $2 \mathrm{~min}$; and a final extension at $72{ }^{\circ} \mathrm{C}$ for $7 \mathrm{~min}$. Annealing temperature was based on a primer melting point (Table 1). The conditions and profiles of PCR reactions have been optimized accordingly. PCR products were analysed by electrophoresis in $2 \%$ agarose gel containing ethidium bromide and TBE buffer ( $\mathrm{pH}$ 8.0); the gels were UV-visualized. Electrophoresis was carried out in a PeqLab electrophoresis system in a $1 \times$ TBE buffer at $85 \mathrm{~V}$ for approximately 5-7 h. The gel was analysed and archived using the Molecular Imager ${ }^{\circ}$ GelDoc ${ }^{\mathrm{n}} \mathrm{XR}$ software (Bio-Rad). Bands were scored and analysed with the Quantity One software (Bio-Rad). The size of the products was determined by comparison with a DNA ladder (MassRuler, Thermo Scientific).

\section{Data analyses}

The presence (1) or absences (0) of the amplified bands were scored in all 9 cultivars for each primer. The polymorphism information content (PIC) value was determined by applying the following formula (RoldanRuiz et al., 2000): PIC $=2 \mathrm{fi}\left(1-\mathrm{f}_{\mathrm{i}}\right)$, where $\mathrm{f}_{\mathrm{i}}$ is the percentage of the amplified alleles (bands present) and $\left(1-f_{i}\right)$ is the frequency of the null allele (band absent) for $\mathrm{i}^{\text {th }}$ allele. Then PIC values were used to calculate the ITAP primer index (IPI); this index was calculated analogically to the indices of other dominant markers, i.e. RAPD - RPI (RAPD primer index) or ISSR-IPI (ISSR primer index), which was generated by summing up the PIC values of all loci amplified by the same primer (Mohanty et al., 2010; Rajwade et al., 2010). The effective multiplex ratio was calculated using the formula: EMR (effective multiplex ratio) $=n \times \beta$, where $n$ is the average number of fragments amplified by accession to a specific system marker and $\beta$ is estimated from the number of polymorphic loci $(\mathrm{PB})$ and the number of non-polymorphic loci $(\mathrm{MB}) ; \beta=\mathrm{PB} /(\mathrm{PB}+$ $\mathrm{MB})$. The marker index for both markers was calculated to characterize the capacity of each primer to detect polymorphic loci among the genotypes. The marker index for each primer was calculated as a product of the polymorphic information content and the effective multiplex ratio (Sornakili et al., 2017): MI = EMR $\times$ PIC. The diversity index (DI) is the average PIC values obtained for all markers (Powell et al., 1996). The assay efficiency Index $(A E I)$ value was also calculated. AEI combines the effective number of alleles identified per locus and the number of polymorphic bands detected in each assay (AEI $=\mathrm{N}_{\mathrm{e}} / \mathrm{P}$, where $\mathrm{N}_{\mathrm{e}}$ is the total number of effective alleles detected and $\mathrm{P}$ is the total number of assays performed for their detection) (Pejic et al., 1998). The genetic similarity index $(\mathrm{Si})$ of the studied populations of Triticosecale was determined in accordance with Dice's coefficient (Dice, 1945) following Nei and Li (1979). A dendrogram was drawn using FreeTree and TreeView programs based on the Nei-Li genetic similarity coefficient with the unweighted pair group method average (UPGMA) clustering. The reliability branching was tested using the bootstrap method with 1000 replications implemented in the UPGMA analysis.

\section{Results and Discussion}

Non-coding sequences constitute a significant part of eukaryotic genomes, and introns (occurring in different proportions in eukaryotes) and intergenic DNA regions, which consist of repeated sequences, can be distinguished among them. The number of repetitive sequences differs depending on the type of organism, e.g. the percentage of repetitive sequences in lower eukaryotes reaches about $20 \%$, while in plant organisms, and this value fluctuates within $50-80 \%$ to even $90 \%$ in some grass species (Szućko and Rogalska, 2015). Among repetitive elements, dispersed and tandem sequences can be distinguished. A significant part of repetitive dispersed sequences are mobile elements that have the ability to integrate their copies into different regions in the genome (Bieniek, 2006). These elements are common in all organisms, however, the number of copies in the genome may be different, or very low, e.g. in Arabidopsis thaliana - $10 \%$, or high - up to $68 \%$ in the wheat genome (Zhang and Wessler, 2004; Li et al., 2004). Marker systems based on mobile elements are widely used to evaluate genomic variability, perform functional gene analysis or establish plant phylogenesis. Research using TE-based markers allows detecting effects of environmental stress causing activation of mobile elements, and thus genetic variability (Alzohairy et al., 2014).

In this study, the experiment was based on the analysis of regions located between transposons belonging to the same family. The ITAP-PCR marker system (developed by Szućko and Rogalska (2015), who used it to analyze the early generations of octoploid triticale) was used for the analysis of DNA transposons in nine hexaploid cultivars of winter triticale. The principle of the ITAP-PCR method is the amplification of regions located between two DNA transposons belonging to the same family (Szućko and Rogalska, 2015). Thanks to this technique, the scale of rearrangement of DNA mobile elements fragments can be assessed and the genetic variability of the analysed individuals can be estimated on this basis. Six primers were selected for the above studies, being fragments of selected transposons, i.e. Mutator, Jude, Caspar, Sherlock, Revolver and Hamlet from cereal genomes of the genus Secale and Triticum. Selected transposons belonged to the following transposon families: Mu, CACTA and Revolver.

The reactions generated products from 277 to 1825 base pairs (Table 2), whereas product sizes in the study of Szućko and Rogalska (2015) ranged from 124 to $3246 \mathrm{bp}$. In addition, 75 bands were generated, of which 73 were polymorphic. It should be noted that the percentage of polymorphic bands in any reaction was not lower than $83.4 \%$, and the average value for all reactions was $95.24 \%$. Szućko and Rogalska (2015) obtained 66 bands in the ITAP-PCR reaction, of which 52 were polymorphic (an average of $78.2 \%$ of the observed bands were polymorphic). Similarity can be noticed comparing the results, although the number of polymorphic bands with respect to the total number of bands is higher in the present study. However, this may be due to the use of a higher number of primers, i.e. 6, while the work of Szućko and Rogalska (2015) used 5. PIC values for dominant markers can oscillate in the range of $0-0.5$; the more the value is closer to 0.5 , the more the primer is better to assess the genetic variation of the analysed 
Table 1. Characteristic of the primers used

\begin{tabular}{ccc}
\hline Primer & Primer sequence $\left(5 \rightarrow 3^{\prime}\right)$ & Ta $\left({ }^{\circ} \mathrm{C}\right)$ \\
Caspar & GGACTAAAGGCTGTTGCGAA & 51.5 \\
Jude & TTCGTGGCAGAACCGGGACT & 58.0 \\
Mutator & CGAGACCAGGGACGAATTTT & 51.5 \\
Revolver & ACGGTTGAGTCTAGGCACAC & 53.0 \\
Sherlock & TTCAGCCGGGTCACTAAGAG & 53.0 \\
Hamlet & TTGGCCCTGT TTACTCGAA & 55.0 \\
\hline
\end{tabular}

Table 2. Averaged coefficients from all test plants obtained by the use of ITAP marker system

\begin{tabular}{|c|c|c|c|c|c|}
\hline Primer & $\begin{array}{c}\text { Total number } \\
\text { of bands }\end{array}$ & $\begin{array}{c}\text { Polymorphic bands } \\
\text { number }\end{array}$ & $\%$ & PIC & Band size (bp) \\
\hline Caspar & 17 & 17 & 100 & 0.36 & $277-1073$ \\
\hline Hamlet & 18 & 18 & 100 & 0.44 & $305-967$ \\
\hline Sherlock & 16 & 16 & 100 & 0.32 & $335-1825$ \\
\hline Revolver & 10 & 10 & 100 & 0.28 & $438-1104$ \\
\hline Jude & 6 & 5 & 83.4 & 0.37 & $373-619$ \\
\hline Mutator & 8 & 7 & 88 & 0.27 & $318-811$ \\
\hline Min. & 6 & 5 & 83.4 & 0.27 & 277 \\
\hline Max. & 18 & 18 & 100 & 0.44 & 1825 \\
\hline Mean & 12.5 & 12.16 & 95.24 & 0.34 & - \\
\hline SD & 5.13 & 5.56 & 7.53 & 0.07 & - \\
\hline
\end{tabular}

material. In this study, the highest PIC value was obtained for the Hamlet primer (0.44) and the lowest for Mutator (0.27), however, it is still an average value and not the lowest.

The average value of this index (DI) was 0.34 (Table 3). DI was at a very similar level as in the work of Szućko and Rogalska (2015) - 0.33. In turn, the average value of this coefficient in a study on winter and spring triticale of Trebichalsky et al. (2013), based on marker systems analysing retro elements, was 0.781 for winter triticale and 0.835 for spring triticale. Tonk et al. (2014), who analysed 16 different triticale genotypes using ISSR and RAPD techniques, obtained the DI value of 0.28 for the RAPD technique and 0.33 for ISSR.

The cereal crop genome is much poorer in DNA transposons compared to retrotransposons or other repetitive elements. The types of TEs selected for this study are the most abundant components of class II, the transposition of which may lead to numerous changes at the genomic level. Literature data indicate that the Hamlet transposon, as well as Caspar, Jude and Sherlock transposons analysed in the above work, belong to the CACTA transposon family. Transposons of this family are often found in barley (Hordeum), wheat (Triticum), goatgrass (Aegilops) and sorghum (Sorghum). The wheat genome contains a minimum of 2,900 copies of the Caspar element, especially the high density of CACTA elements observed at the Glu-A3 loci (encoding glutenins) (Wicker et al., 2003b). Location in the proximity of important gene in wheat genome indicates, that there is the possibility of affecting neighbouring sequences in case of genetic/epigenetic changes concerning transposon. There have been no studies on the presence of this transposon in triticale. Wicker et al. (2003a) localized the Sherlock transposon in barley and demonstrated that its transposition led to DNA instability caused by numerous chromosome rearrangements.
Transposons belonging to the CACTA family are believed to cause numerous duplications and deletions leading to genomic instability. It has been demonstrated that elements belonging to the Caspar family contain short region (64-bp) identical in $81 \%$ to a part of the $5 \mathrm{~S}$ rDNA gene from Triticum monococcum. This part of gene is involved in the recruitment of transcription factors (corresponds to the internal RNA polymerase III promoter) (Wicker et al., 2003a). In turn, Mutator belongs to the $M u$ transposon family. The $M u$ transposon family is present in many different and potentially functional variants. A particularly high level of their activity was demonstrated in maize, in which they were identified for the first time (Lisch, 2002; Xian-Min and Lisch, 2006. Mu has the ability to transpose into any chromosome, thereby causing very high mutation frequency. Insertion of these elements tend to be into or near genes, and a lot of loci appear to be potential targets e.g. Sul loci (involved in kernel development), APETELA2 gene (involved in spikelet development) and Knotted 1 gene (involved in leaf development) (Xian-Min and Lisch, 2006). Transposons belonging to the $M u$ family are one of the most mutagenic transposon families of plants and have become the main tool for gene tagging (Xian-Min and Lisch, 2006). Mu-like elements have also been identified in monocotyledonous and dicotyledonous plants. The Revolver transposon (0.28) was also characterized by a low PIC coefficient. Revolver is considered to belong to the group of class II transposons, but its sequences differ from the classic DNA transposons. Revolver, called a transposonsimilar mobile element, is present in the genomes of the Triticum species.

Tomita et al. (2009) showed that the Revolver family is transcriptionally active in rye (Secale sp.). No transcript of this mobile element was detected in common wheat (Triticum aestivum), and weak transcripts were located in translocation wheat lines with rye chromosomes. 
Table 3. Indexes describing the method used

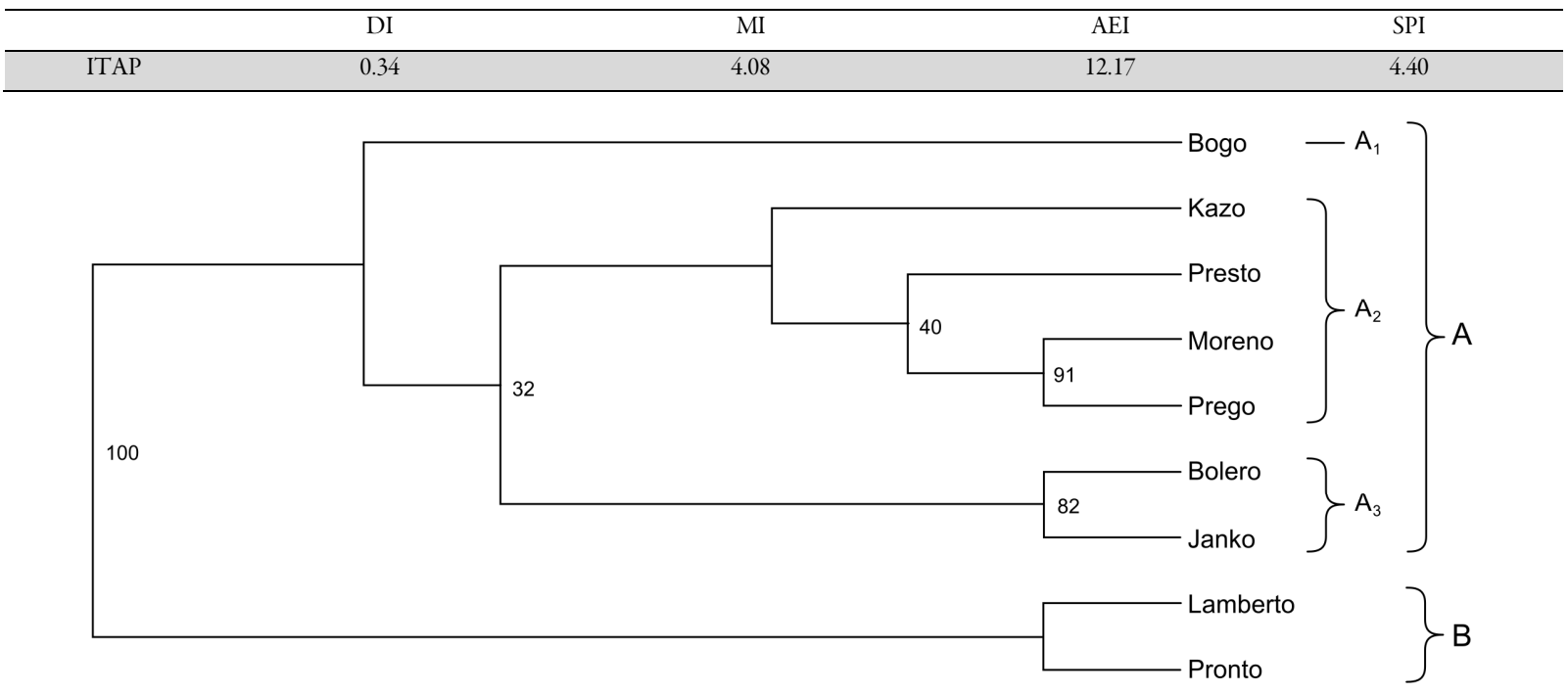

Fig. 1. Dendrogram of triticale based on Nei's genetic distance obtained from ITAP markers using the UPGMA algorithm. Numbers on branches refer to bootstrap values (1,000 replications)

In addition to the above-mentioned species, this element was also localized in Dasypyrum villosum, Triticum monococcum, Aegilops speltoides, Triticum dicoccum and Aegilops taushii. This indicates that Revolver is amplified in rye and other diploid species. This element is a valuable source of information about the evolutionary relationships within the Triticeae family, because it has dynamically influenced their evolution (Tomita and Tanaka, 2011). This study also identified its presence in the Triticosecale Witt. hexaploid cultivars. Quite high MI values (4.08), using such a low number of primers, indicate that this technique is suitable for assessing the genetic variation of the analysed forms; the higher the MI values, the more useful the technique for analysing genetic variation (Chesnokov and Artemyeva, 2015). Kalinka and Achrem (2018), analyzing octoploid triticale forms, used compilations of molecular markers and obtained the following MI values: IRAP (5.46), REMAP (1.95), ISSR (2.42), while Szućko (2013), who also analysed early generations of octoploid wheat and rye hybrids obtained the following values: ITAP (3.06), IRAP (5.83), REMAP (2.17), ISSR (6.81). In turn, the MI value for the ISSR method in the study of Tonk $e t$ al. (2014) was 1.58 and 1.23 for RAPD.

The IPI index in the above studies was 4.40, while the assay efficiency index (AEI) was 12.17. In the aforementioned studies, Szućko (2013) obtained the following AEI values: ITAP (8.86), IRAP (16.20), REMAP (6.41) and ISSR (17.63).

SI coefficient showed that 'Bogo' and 'Lamberto' (36.7\%) and 'Bogo' and 'Pronto' (39.4\%) were the most distant cultivars, while 'Moreno' and 'Prego' (81.7\%) were the most similar variants of the analyzed ones. In turn, Tonk et al. (2014) obtained SI at the level of $65-93 \%$. The genetic similarity of triticale cultivars was evaluated using the UPGMA algorithm based on the data obtained in the present study. Genetic similarity analysis of triticale cultivars has led to the isolation of two cluster groups, which indicated genetic distinctiveness of the cultivars contained in them. The first group (A) was more complex than the second group (B). Three subgroups could be identified in group $A\left(A_{1}-A_{3}\right)$. Subgroup $A_{1}$ included the cultivar 'Bogo' from 1986, subgroup A $A_{2}$ 'Kazo' (2000), 'Presto' (1989), 'Moreno' (1992) and 'Prego' (1991) cultivars. 'Presto' and 'Prego' cultivars clustered into one subgroup, which was consistent with the study of Milczarski et al. (2001), although the latter authors used a different marker system RAPD. 'Bolero' (1993) and 'Janko' (2000) cultivars were in subgroup $A_{3}$. High bootstrap values (82) indicated a significant probability of such grouping. In turn, group B contained two triticale cultivars - 'Lamberto' (1998) and 'Presto' (1999). Separation of these two cultivars from the other analysed was highly probable (bootstrap $=100$ ). However, this was not consistent with the study of Milczański et al. (2001), who assigned the cultivar 'Lamberto' to one group with the cultivar 'Bogo', forming subgroup A1 in the aforementioned study.

Although the literature data indicate that retrotransposons, present in a high number of copies in plant genomes, showing variation both at the intra- and interspecific level, are the richest source of polymorphic markers (Waugh et al. 1997; Gawłowska et al., 2010), it seems that class II elements (DNA transposons) can also be a potential tool for analysing cereal plants, especially triticale.

We have determined that the used transposon-based marker provided sufficient level of polymorphism. All cultivars examined could be separated from each other. The constructed UPGMA dendrogram grouped all samples into two main clusters. Taking into account all the results (MI, DI, AEI, IPI and dendrogram features), we can confirm that the ITAP technique of transposon-based marker is an efficient and rapid method to detect the genetic variability between genetically related triticale genotypes. So far, no studies have been conducted on the rearrangements of these elements in these hexaploid cultivars. The selected marker system used in earlier studies to assess genomic changes 
952

occurring in early triticale generations (Szućko and Rogalska, 2015) proved useful in the above analyses. Moreover, the analysis and interpretation of the results using this technique are relatively simple and their cost is relatively low compared to other more complex molecular biology techniques.

\section{Conflict of Interest}

The authors declare that there are no conflicts of interest related to this article.

\section{References}

Achremowicz B, Puchalski C, Haber T (2015). Wykorzystanie ziarna pszenżyta w przemyśle fermentacyjnym [Technological applicability of triticale grain]. Advances in Processing Technologies Food Industry 1:113-120.

Alheit KV, ReifJC, Maurer HP, Hahn V, Weissmann EA, Miedaner T, Wurschum T. (2011). Detection of segregation distortion loci in triticale ( $\times$ Triticosecale Wittmack) based on a high-density DArT marker consensus genetic linkage map. BMC Genomics 12(1):380.

Alzohairy AM, Gyuali G, Ramadan MF, Edris S, Sabir JSM, Jansen RK, ... Bahieldin A (2014). Retrotransposon-based molecular markers for assessment of genomic diversity. Functional Plant Biology 41(8):781789.

Bieniek W (2006). Markery DNA oparte na retrotranspozonach [Retrotransposon-basedDNA marker]. Botanical News 50:15-24.

Bingham PM, Kidwell MG, Rubin GM (1982). The molecular basis of PM hybrid dysgenesis: The role of the $P$ element, a P-strain-specific transposon family. Cell 29(3):995-1004.

Chesnokov YV, Artemyeva AM (2015). Evalution of polymorphism information of genetic diversity. Agricultural Biology 50(5):571-578.

Dice LR (1945). Measures of the amount of ecologic association between species.Ecology 26(3):297-302.

Emmons SW, Yesner L, Ruan KS, Katzenberg D (1983). Evidence for a transposon in Caenorhabditiselegans. Cell 32(1):55-65.

Flavell AJ, Knox MR, Pearce SR, Ellis THN (1998). Retrotransposon-based insertion polymorphisms (RBIP) for high throughput marker analysis. The Plant Journal 16(5):643-650.

Furman BJ, Qualset CO, Skovmand B, Heaton JH, Corke H, Wesenberg $\operatorname{DM}(1997)$. Characterization and analysis of North American triticale genetic resources. CropScience 37(6):1951-1959.

Gao D, Jiang N, Wing R, Jiang J, Jackson S (2015). Transposons play an important role in the evolution and diversification of centromeres amongclosely related species. Frontiers in Plant Science 6:216.

Kalendar R (2011). The use of retrotransposon-based molecular markers to analyze genetic diversity. FieldandVegetable Crops Research 48:261274.

Kalendar R, Antonius K, Smykal P, Schulman AH (2010). iPBS: A universal method for DNA fingerprinting and retrotransposon isolation. Theoretical and Applied Genetics 121(8):1419-1430.

Kalinka A, Achrem M (2018). Reorganization of wheat and rye genomes in octoploid triticale. Planta 247(4):807-829.
Kamboj RK, Mani SC (1983). Genetic divergence in triticale. Indian Journal ofGenetics and Plant Breeding 43:173-179.

Kramek A, Kociuba W (2014). Charakterystyka zasobów genowych pszenżyta ozimego pod względem polowej odporności na choroby grzybowe [Characteristics of winter Triticale genetic resources regarding field resistance to fungal diseases]. Annales Universitatis Mariae CurieSkłodowska Lublin-Polonia. SectioE:69:113-117.

Kuleung C, Baenziger PS, Dweikat I (2006). Evaluating the genetic diversity of triticale with wheat and rye SSR markets. Crop Science 46(4):16921700.

Li W, Zhang P, Fellers J, Friebe B, Gill B (2004). Sequence composition, organization, and evolution of the core Triticeae genome. The Plant Journal 40(4):500-511.

Lisch D (2002). Mutator transposons. Trends in Plant Science 7:498-504.

Lu L, Chen J, Robb SM, Okumoto Y, Stajich JE, Wessler SR (2017). Tracking the genome-wide outcomes of a transposable element burst over decades of amplification. Proceedings of the National Academy of Sciences of the United States of America 114(49):E10550-E10559.

MaX-F, Gustafson J (2008). Allopolyploidization-accommodated genomic sequence changes in Triticale. Annals of Botany 101(6):825-832

Machczyńska J, Zimny J, Bednarek PT (2015). Tissue culture-induced genetic and epigenetic variation in triticale ( $\mathrm{x}$ Triticosecale spp. Wittmack ex A. Camus 1927) regenerants. Plant Molecular Biology 89(3):279292.

Milczarski P, Banek-Tabor A, Masojć P (2001). Wykorzystanie markerów RAPD do identyfikacji odmian pszenżyta [Application of RAPD markers for fingerprinting of triticale cultivars]. Biulletin of Plant Breeding Acclimatization Institute IHAR 218/219:261-266.

McClintock B (1954) Mutations in maize and chromosomal aberrations in Neurospora. Carnegie Institution of Washington Year Book (Carnegie Institution of Washington, Washington, DC) pp 254260.

Mohanty S, Das AB, Ghosh N, Panda BB, Smith DW (2010). Genetic diversity of 28 wild species of fodder legume Cassia using RAPD, ISSR and SSR markers: anovel breeding strategy. Journal of Biotech Research 2:44-55.

Muehlbauer GJ, Bhau BS, Naeem BH, Syed NH, Shane H, Cho S, ... Flavell AJ (2006). A $h A T$ superfamily transposase recruited by the cereal grass genome. Molecular Genetics and Genomics 275(6):553-563.

Nei M, Li W (1979). Mathematical model for studying genetic variation in terms of restriction endonucleases. Proceedings of the National Academy of Sciences of the United States of America 76(10):52695273.

Orlovskay OA, Joren LV, Khotyleva (2012). Genetic polymorphism evaluation of spring triticale ( $\mathrm{x}$ Triticosecale Wittmack) samples with use of RAPD and ISSR markers. Russian Journal of Genetics 2(6):508-512.

Pejic I, Ajmone-Marsan P, Morgante M, Kozumplicck V, Castiglioni P, Taramino G, Motto M (1998). Comparative analysis of genetic similarity among maize inbred lines detected by RFLPs, RAPDs, SSRs, and AFLPs. Theoretical and Applied Genetics 97(8):1248-1255.

Powell W, Morgante M, Andre C, Hanafey M, VogelJ, TingeyS, Rafalski A (1996). The comparison of RFLP, RAPD, AFLP and SSR (microsatellite) markers for germplasm analysis. Molecular Breeding 2(3):225-238. 
Rajwade AV, Arora RS, Kadoo NY,Harsulkar AM, Ghorpade PB, Gupta VS (2010). Relatedness of Indian flax genotypes (Linum usitatissimum L.): an inter-simple sequence repeat (ISSR) primer assay. Molecular Biotechnology 45(2):161-170.

Ramirez-Garcia J, Gabriel JL, Alonso-Ayuso M, Quemada M (2015). Quantitative characterization of five cover crop species. The Journal of Agricultural Science 153(7):1174-1185.

Roldán-Ruiz I, Dendauw J, Van Bockstaele E, Depicker A, De Loose M (2000). AFLP markers reveal high polymorphic rates in ryegrasses (Lolium spp.). Molecular Breeding6(2):125-134.

Rogalska S, Kalinka A, Achrem M, Słomińska-Walkowiak R, Skuza L, Filip E (2004). Genetyczne elementy ruchome u roślin i innych organizmów [Transposable elements in plants and other organisms]. Space 3(53):325-342.

Seidl MF, Thomma BPHJ (2017). Transposable elements direct the coevolution between plants and microbes. Trends in Genetics 33(11):842-851.

Sornakili A, Rathinam PK, Thiruvengadum R, Kuppusamy P (2017). Comparative assessment of RAPD and ISSR markers to study genetic polymorphism in Colletotrichum gloeosporioides isolates of mango. Asian Journal of Plant Pathology 11:130-138.

Szućko I, Rogalska SM (2015). Application of ISSR-PCR, IRAP-PCR, REMAP-PCR, and ITAP-PCR in the assessment of genomic changes in the early generation of triticale. Biologia Plantarum 59(4):708-714.

Szućko I (2014). Zmiany sekwencji nukleotydowych DNA w genomach mieszańców pszenno-żytnich [Changes of nucleotide sequences of DNA in the genomes of wheat-rye hybrids]. PhD Thesis 2013.

Tomita M, Tatsurou Noguchi T, Taihachi Kawahara T (2009). Quantitative variation of Revolver transposon-like genes in synthetic wheat and their structural relationship with the LARD element. BreedingScience 59:629-636.
Tomita M, Tanaka E (2011). Genomic and RNA divergences of Revolver transposon-like gene offer chromosome tags in Triticeae. Molecular Genetics Laboratory, Tottori University pp 1-3.

Tonk FA, Tousn M, Ilker E, Istipliler D, Tatar O (2014). Evalutaion and comparison of ISSR and RAPD markers for assessment of genetic diversity in triticale genotypes. Bulgarian Journal of Agricultural Science 20(6):1413-1420.

Trebichalsky A, Kalendar R, Schulman A, Stratula O, Galova Z, Balazova Z, Chnapek M (2013). Detection of genetic relationschips among spring and winter triticale (xTriticosecale Witt.) and rye cultivars (Secale cereale L.) by using retrotransposon-based markers. Czech Journal of Genetic and Plant Breeding 49(4):171-174.

Wicker T, Yahiaoui N, Guyot R, Schlagenhauf E, Liu Z-D, Dubcovsky J, Keller B (2003a). Rapid genome divergence at orthologous LMW glutenin loci of the $A$ and $A^{\mathrm{m}}$ genome of wheat. Plant Cell 15(5):11861197.

Wicker T, Guyot R, Yahiaoui N, Keller B (2003b). CACTA Transposons in Triticeae. A Diverse Family of High-Copy Repetitive Elements. Institute of Plant Biology. Plant Physiology 132(1):52-61.

Xian-Min D, Lisch D (2006). Mutator transposon in maize and MULES in the plant genome. Acta GeneticaSinica 33(6):477-486.

Yaakov B, Kashkush K (2011). Methylation, transcription, and rearrangements of transposable elements in synthetic allopolyploids. International Journal of Plant Genomics 569826.

Zhang X, Wessler S (2004). Genome-wide comparative analysis of the transposable elements in the related species Arabidopsis thaliana and Brassica oleracea. Proceedings of the National Academy of Sciences of the United States of America 101(15):5589-559. 